\title{
COMPUTER-AIDED ENVIRONMENTAL RISK ASSESSMENT OF POTATO CULTIVATION TECHNOLOGY USING OPENLCA SOFTWARE
}

\author{
Jerzy Grudziński', Monika Krzywicka' ${ }^{1}$, ${ }^{1}$ kasz Bolibok ${ }^{1}$ \\ 1 Chair of Technology Fundamentals, University of Life Sciences in Lublin, Doświadczalna 50a, 20-950 Lublin, \\ Poland, e-mail: jerzy.grudzinski@up.lublin.pl, monika.gruszecka@up.lublin.pl, lukasz.bolibok@up.lublin.pl
}

Received: 2016.08.01

Accepted: 2016.09.26

Published: 2016.11.01

\begin{abstract}
The article discusses the environmental impact of the tillage processes of potato production. The analysis was performed using a simplified LCA ( Life Cycle Assessment) software. Depending on the purpose and the level of detail of the process analysis, the LCA technique of environmental management may require computer assistance. Even then, carrying it out is very complex, long and costly. The aim of the study was to explore the possibility of the use of open source software for a simplified life-cycle analysis of potato with LCA method. There was selected OpenLCA - GreenDelta TC GmbH, v.1.3.1 software. The diagrams of unit process streams and energy inputs incurred on the individual processes of cultivation were designed based on literature. There were compared environmental hazards of the two systems of potato cultivation: with using the plough and the simplified one in terms of atmospheric pollution with chemicals emitted by the engines of agricultural tractors in the course of the subsequent agricultural procedures. The study results confirmed the suitability of the software for the initial evaluation (screening) of environmental hazards using LCA method. The software is compatible with both the open source databases and commercial databases. Environmental impacts of cultivation technologies are presented in a form of a graphic illustration of pollution emissions. Also, the problems hindering the use of the software are indicated.
\end{abstract}

Keywords: OpenLCA, environmental impacts, cultivation of potato

\section{INTRODUCTION}

Agriculture, both in terms of breeding and tillage, is a source of very significant environmental burden. It is estimated that in Europe, $29 \%$ of global greenhouse gas emissions come from the production and processing of food. Potato production, regardless of the cultivation system requires incurring significant expenditure of energy, which causes environment pollution [Jablonski K., 2006].

Poland is a significant producer of potato, it has the world's fourth acreage - about 30000 ha and generates $8.4 \%$ of world production. At the same time the yields of most crops, located in the areas of significant fragmentation of agriculture, are among the lowest in Europe, and amounted according to the GUS (Central Statistical Office of Poland) to an average of $210 \mathrm{dt} /$ ha in 2015 [www.stat.gov.pl].

Cultivation of potato is characterized by high energy consumption and capital intensity [Klikocka 2006, Khoshnevisan et al. 2013]. Cultivation technology depends on many, sometimes difficult-to-predict factors: the purpose of the product, area of cultivation, crop rotation, fertilization, intercropping, method of cultivating the soil, the seed, weather conditions and others. The main objective adopted currently in potato cultivation is getting stable and high-quality crop conforming to standards in its production at a constant reduction in the unit cost of cultivation [Jablonski 2009, Nowacki 2012]. Currently, there are the following systems of potato cultivation: 
conventional extensive, conventional balanced, conventional intensive, integrated certified production system, certified ecological system, other certified voluntary standards for obtaining high quality of the crop [Nemecek et al. $2011 \mathrm{a}, \mathrm{b}$, Nowacki 2012, Zarzecka 2014].

In Poland, the most common system of potato cultivation is a low cost conventional system. It covers about $30 \%$ of the total acreage of potato cultivation, mainly small surface plantations and therefore found in a large number of farms. Specific features of this system include the low rate of using certified plants, low fertilization, but compensated by widespread use of manure, simplified mechanical care, narrow inter-rows $(50$ or $62.5 \mathrm{~cm})$, occasional protection of plants against fungal diseases $(0-2$ treatments during the growing season) and a low level of mechanization of cultivation. The consequences of the use of this system are low and unstable yields, a high share of crop waste and generally low profitability of production.

The integrated production (IP) of potato is the most balanced and closest to the currently used system of cultivation in medium-sized farms in the country. It is characterized by moderate levels of fertilization supplemented with the use of natural fertilizers, the use of crop rotation and moderate pest control determined by the thresholds of economic harm due to potato agrophages. The basis for the use of IP is the proper selection of varieties for the conditions of the natural environment, which in turn generates a fairly good profitability Cultivation of potato in the ecological management system is extremely difficult and that is why organic farms avoid the cultivation of this species. The main barriers include the difficulty in protecting plantations against Colorado potato beetle and potato blight, inefficient mechanical weed control of plantations and low and often flawed in terms of market standards tuber yields. Cultivation of potato considered difficult and labor-intensive is displaced from organic farms by other agricultural species [Nowacki 2012, Stachowicz 2011].

Research on the possibility of simplifying the process of growing and processing of potatoes without a significant reduction in yields and product quality has long been conducted [Jabłoński K.2006, 2009]. The motivation to undertake such research is economic and energy aspects, i.e. reducing consumption of energy used for production, thereby reducing costs. In contrast, research on environmental aspects of agricultural crops is underrepresented [Tasca et al. 2016]. The technique of Life Cycle Assessment (LCA) is mainly used to compare the environmental impacts of competitive production technologies and industrial products [Stavropoulos et al. 2016]. The complexity of the assessment processes requires the use of computer assistance. Renowned IT companies offer programs with a high degree of versatility, which translates into a very high cost and laboriousness of environmental analyzes. They cause the discouragement of policy makers to include such analyzes in cycle of pre-production, especially in the small and medium-sized enterprises. In many situations, especially when in the preparation of production the time is an important factor, there is no need for a very detailed analysis of the environmental impacts. There is a need for simplified, low-cost and fast methods of computer support. Such tools are offered by various academic and social institutions as free "open source" systems. The following are examples of tools for preliminary analysis of environmental impacts of the evaluated products.

1. Economic Input-Output LCA method (EIOLCA method) offered by the Green Design Institute at Cornegie Mellon University (USA), based on the work of eminent economist Vassily Leontief, Nobel Prize winner in economics. It enables the direct designation of the environmental impacts of the product, taking into account cost of raw materials, production, consumption, [http://www.eiolca.net],

2. Economy Map - Jason Pearson 2011 supported by database LCA CEDA 5, [http://www.economymap.org],

3. Fast Footprinting Methods - LinkCycle Boston, [http://www.linkcycle.com],

4. Open LCA - Green Delta TC GmbH, [http://www.openlca.org/],

5. SENSE - European research project carried out in 2012-2015, in an attempt to standardize the methods for environmental assessment of food products, dedicated to small and medium agri-food sector. Currently webbased system has been created in the field of wine production, breeding and processing of salmon and dairy farming and meat. [http://www.senseproject.eu] 


\section{GOAL AND SCOPE}

The aim of this work was to study the use of Open LCA- GreenDelta TC GmbH, v.1.3.1 software to analyze the life cycle of potatoes in terms of pollution emission during the tillage and potato-lifting. We compared two different cultivation technologies: conventional (ploughing) and simplified, characterized by fewer agricultural treatments. The variants of the technological process are typical for the southern Lublin region in the period from autumn postharvest cultivation to potato-lifting. Energy expenditure incurred on the various stages of cultivation was based on [Sachajko J. 2010, Soloch 2010]. The study conducted in 2006-2009 concerned the potatoes IRGA (Solanum tuberosum L.) planted in the $100 \mathrm{~m}$ long field. For cultivation, there was used a farm tractor URSUS C360 3P with equipment adapted to the subsequent unit processes of cultivation.

When assessing the environmental risks, the results of the yield of potatoes were not taken into account due to minor differences in the two cases [Jabłoński 2006, Sachajko 2010].

The environmental hazards were compared in terms of atmospheric pollution with chemicals emitted by the engines of agricultural tractors in the course of the subsequent unit cultivation processes and harvesting of potatoes.

The input data of the OpenLCA program was the fuel consumption of agricultural tractor URSUS C360 3P - diesel fuel estimated for each tillage process based on literature [Linden et al. 2014, Merkisz et al. 2013].

Determination of the quantities of exhaust emissions, as well as their chemical composition of the agricultural tractor working on a field for significant amount of time in the transient state, using engine power based on other difficult to determine numerical factors, is virtually impossible. There are attempts to modeling averaged fuel consumption of tractor engines for different processes of cultivation of various crops referenced to time, growing area, soil type and many other difficult to estimate factors [Linden et al. 2014]. Stand testing exhaust emissions of internal combustion engines in a cycle of movement of the vehicle in off-road conditions were carried out by Paconek et al. [2010]. At the initial stage there are investigations of emission tractors diesel engines under real operating conditions using mobile analyzers PEMS [Merkisz et al. 2013].
Therefore, the amount of consumed by the tractor engine fuel of chemical composition: $\mathrm{C}-87 \% \mathrm{H}-12 \% \mathrm{~S}-1 \%$ [Pawuła et al. 2010] was converted into the amount of exhaust emissions with a predetermined chemical composition of exhaust gases. Thus obtained values were inserted as input to the OpenLCA program.

LCA technique involves four phases:

1. Purpose and scope. The study objective analysis of the LCA is to select the more favorable variant of the technology of potato cultivation with less impact on the environment. The scope of research includes determining the boundaries of research, assumptions and limitations.

2. A life cycle inventory includes data collection, the design of streams of unit processes specifying inputs and outputs, product system design This phase is offset that which enters the system and what it leaves.

3. Life cycle impact assessment (LCIA). Assignment of data collection to specific environmental impacts: the choice of categories of influence, category indicators and characterization models, assigning LCI results - classification, the calculation of the indicator category. Optional is a grouping of results, weighing and analysis of data quality

\section{Interpretation of results.}

The technological processes of both compared systems are presented in Table 1 .

Table 1. Subsequent unit processes of the traditional and simplified systems including implements and effort needed [source: Sachajko 2010].

\section{DETERMINATION OF THE ENVIRONMENTAL IMPACT OF CULTIVATION OF THE POTATO IN THE LIFE CYCLE}

The program OpenLCA before modelling requires data format EcoSpold or ILCD. As the method LCA was originally addressed to the ecological assessment of products and industrial technology, free databases tailored for use with the program consists mainly of such data. There are relatively few data on agricultural production. Therefore, the first assessment of the risks in the life cycle of potato from soil preparation to har- 
vesting and transport to storage using the database "Potato, whole plant, at field.xml" offered free of charge by OpenLCA.

Studied differences in results arising from the use of different methods of modelling LCA.

Figure 1 shows. graphic interpretation magnitude of environmental impacts in the different categories of influence in the LCA "cultivation of potatoes."

\section{RESULTS AND CONCLUSIONS}

The results confirmed the suitability of the software for the initial screening of environmental impacts using LCA method. Using the program requires precise knowledge of the relationship between each unit process. The main problems occurring during data collection are the limitations in the availability of the databases (most of them are payable) and lack of information about their contents. There is no possibility to obtain the exact amount of the gases emitted by agricultural tractor at the time of conducting all appropriate operations. The problem in wide dissemination of the program in the country can be lack of translated user interface into Polish (there is a choice of English and some other languages user interface).
Environmental hazards of the both compared cultivation technologies are presented in the form of a graphic illustration of emissions. There are indicated unit processes having the greatest impact on air pollution and there are proposed alternatives to minimize the environmental burden.

\section{REFERENCES}

1. Economic Input-Output LCA (EIO-LCA). Green Design Institute at Cornegie Mellon University (USA). Available online: http://www.eiolca.net, accessed online on 6/05/2016

2. Economy Map - Jason Pearson. 2011. Available online: http://www.economymap.org, accessed online on 6/05/2016

3. Filip A., Samson-Bręk I. 2011. Miejsce oceny cyklu życia w systemie zarządzania środowiskowego. Studia Ecologiae et Bioethicae UKSW 9,4, 65-77

4. GreenDelta GmbH. OpenLCA. Available online: http://www.openlca.org, accessed online on 6/05/2016

5. Jabłoński K. 2006. Agrotechniczne i ekonomiczne efekty uproszczonej uprawy roli pod ziemniaki, Inżynieria Rolnicza, 3(78), 21-30

6. Jabłoński K. 2009. Nowe elementy w technice i technologii produkcji ziemniaków. cz. I. Uprawa

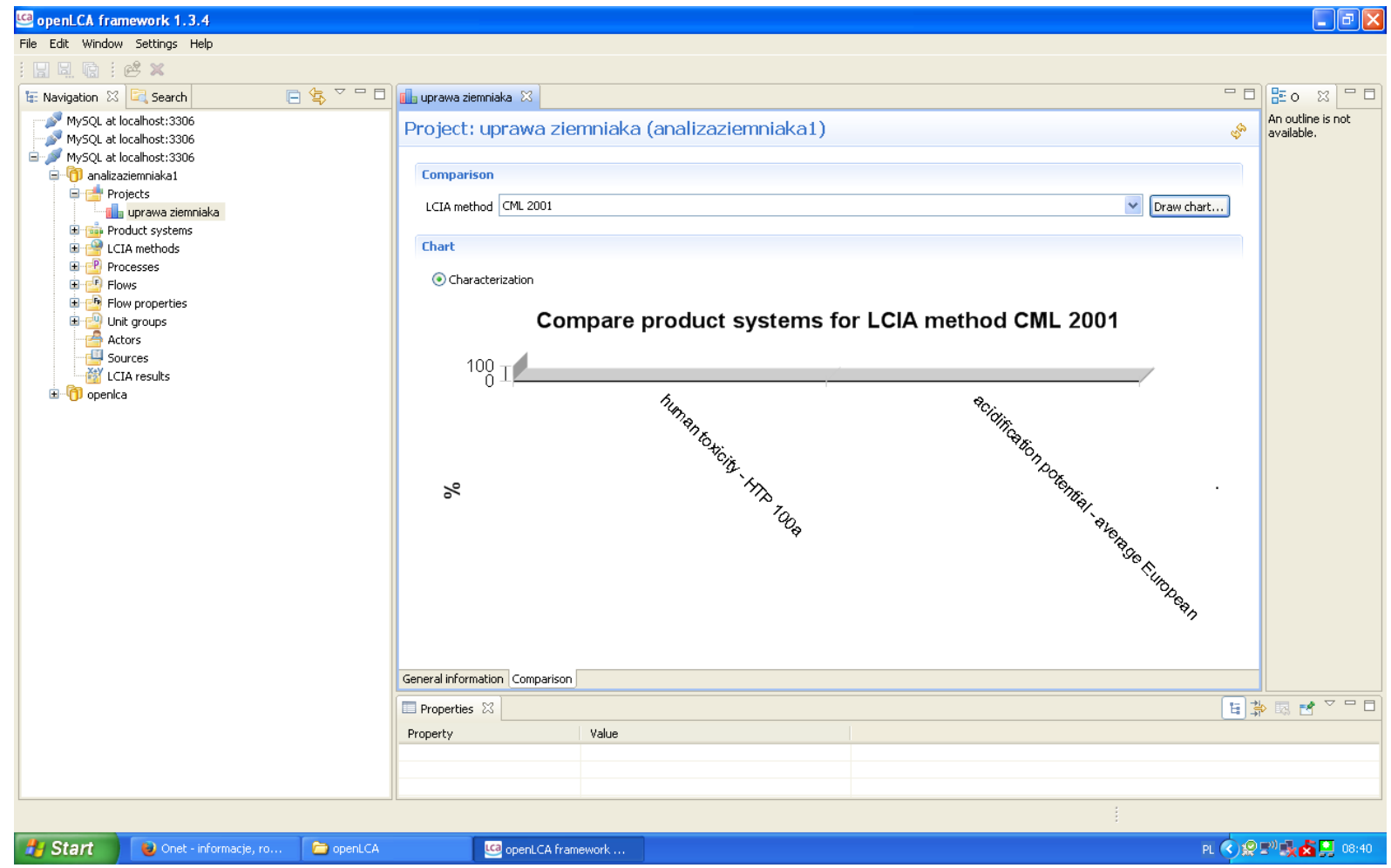

Fig. 1. Graphical representation of environmental impacts for LCIA method CML 2001: human toxicity and acidification potential. 
gleby, nawożenie i sadzenie. Technika Rolnicza, Ogrodnicza i Leśna, 4,. 23-26

7. Khoshnevisan B. et al. 2013. Prognostication of environmental indices in potato production using artificial neural networks. Journal of Cleaner Production, 52, 402-409

8. Klikocka H. 2006. Efektywność energetyczna różnych sposobów uprawy roli i nawożenia naturalnego w produkcji ziemniaka. Acta Agrophysica, v. $8,2,385-393$

9. LinkCycle Boston. Fast Footprinting Methods. Available online: http:/www.linkcycle.com, accessed online on $6 / 05 / 2016$

10. Linden V.V. et al. 2014. A fuel consumption model for off-road use of mobile machinery in agriculture. Energy 77, http://dx.doi.org/10.1016/j.energy.2014.09.074, 880-889

11. Merkisz J. et al. 2013. Exhaust emission tests from non-road vehicles conducted with the use of PEMS analysers. Maintenance and Reliability, vol.15, No 4, 364-368

12. Nemecek T. et al. 2011. Life cycle assessment of Swiss farming systems: I. Integrated and organic farming. Agricultural Systems 104, 217-232

13. Nemecek T. et al. 2011. Life cycle assessment of Swiss farming systems: II. Extensive and intensive production. Agricultural Systems 104, 233-245

14. Nowacki W. 2012. Integrated production of potato in relation to different potato cultivation systems. Prog.Plant Prot., 52 (3), 740-745

15. Paconek A. et al. 2010. Budowa stanowiska do generowania i analizy spalin z wysokoprężnego silnika Diesla. Inż. Ap. Chem., 49,1, 83-84

16. Pawuła A. et al. 1994. Koreferat do dokumentacji hydrologicznej dotyczącej oddziaływania na środowisko gruntowo-wodne bazy paliw płynnych PPH „Syndrom” w Śremie. Poznań-Kiekrz. Avail- able online: http://www.staff.amu.edu.pl/ pawula/ SREM1.htm, accessed online on 4/06/2016

17. Sachajko J. 2010. Ocena produkcyjna, ekonomiczna i energetyczna uprawy ziemniaka oraz pszenżyta jarego w warunkach zróżnicowanej agrotechniki. Praca doktorska, Zamość, UP Lublin

18. SENSE - Harmonised Environmental Sustainability in the European food \& drink chain, available online: http://www.senseproject.eu, accessed online on $1 / 08 / 2016$

19. Soloch J. 2010. Technologia uprawy ziemniaków jadalnych. LODR Oddz. Lubniewice. Available online: http:/www.tractoor.pl/produkcja-rolinna/ uprawa-rolin-i-gleby/1867-technologia-uprawyziemniaków-jadalnych.pdf, accessed online on $6 / 05 / 2016$

20. Stachowicz T. 2011. Uprawa ziemniaków w gospodarstwie ekologicznym Available online: http:// www.odr.net.pl/rolnictwo_ekologiczne, accessed online on 6/05/2016

21. Stavropoulos P. et al. 2016. Life cycle analysis: comparison between different methods and optimization challenges. Procedia CIRP, 41, 626-631

22. Tasca A.L., et al. 2016. Evironmental sustainability of agri-food supply chains: An LCA comparison between two alternative forms of production and distribution of endive in northen Italy. J. of Cleaner Prod., http://dx.doi.org/10.1016/j. jclepro.2016.06.170, 1-17

23. Wyniki produkcji roślinnej w 2015r. 2016. Central Statistical Office of Poland-GUS Warszawa. Available online: http://www.stat.gov.pl, accessed online on $6 / 05 / 2016$

24. Zarzecka K. 2014. Technologia uprawy ziemniaka w zrównoważonym systemie gospodarowania (praca przeglądowa). Biuletyn Instytutu Hodowli i Aklimatyzacji Roślin, 272, 113-127

Pracę dofinansowano ze środków Wojewódzkiego Funduszu Ochrony Środowiska i Gospodarki Wodnej w Lublinie. 